\title{
Effect of frother and depressant interaction on flotation of Great Dyke PGM ore
}

\author{
by T. Mberi* ${ }^{*}$ L.L. Mguni*, and F. Ntuli†
}

\begin{abstract}
Synopsis
In the optimization of platinum group metal flotation plants, various parameters are considered in order to achieve the desired recovery and grade of the precious metals. There should be a balance in the operating parameters so as to produce a high-grade valuable mineral concentrate without compromising recovery. This project seeks to investigate the individual and interactive effect of flotation reagents at different dosages, using a full factorial experimental design approach with two factors at six levels. Laboratory tests were conducted to illustrate the effect of frother and depressant on flotation. The results were analysed using SPSS and MiniTab. Based on the F-test at $95 \%$ confidence level, the frother had no significant effect on the concentrate grade but had a significant effect on $4 \mathrm{E}$ recovery, mass pull, and water recovery. The depressant had a significant effect on concentrate grade, water recovery, and mass pull. The interactive effect of frother and depressant had significant negative effect on all responses except concentrate grade. The optimum levels for recovery and grade were analysed assuming equal importance of grade and recovery as well as double importance for grade.
\end{abstract}

\section{Keywords}

froth flotation, PGMs, flotation reagents, frother, depressant, interactive effect.
The primary collector used in ore flotation is xanthate. A depressant is added to suppress naturally floating gangue minerals.

Optimization of reagents has been traditionally performed by varying one while keeping the others fixed. This method ignores interaction effects among reagents. Changes in reagent dosage to achieve a particular outcome may have secondary effects that override the desired effect, hence interactions have to be well understood if optimization is to be achieved. Little work has been reported on the flotation performance of Great Dyke ore. Nashwa (2008) reported on the effect on SIBIX and SIBIX-TTCs blends, but most of the work that has been reported is based on Bushveld Complex ore. Interaction effects between aeration rate and froth have been reported by Venkatesan and Harris (2014). The work showed that interaction effects were significant at conditions of high air flow rate $(40 \mathrm{~m} / \mathrm{s}$ ) and cell level (max. $95 \%$ cell level). In other work based on UG2 ore, McFadzean and Pani (2015) reported on interactive effects between depressant, frother, froth height, and superficial air velocity. They reported that among the process parameters, superficial air velocity had the dominant effect on chromite and PGM recovery, while depressant had a dominant effect only on chromite grade.

In this research, the interactive effects of depressant and frother were investigated while collector dosage was held constant. A twofactor analysis with six levels was done so as to observe the individual and interactive effects of frother and depressant on $4 \mathrm{E}$ (platinum, palladium rhodium, plus gold) recovery, grade, mass pull, and water recovery using PGM-bearing ore from the Great Dyke.

* National University of Science and Technology, Bulawayo, Zimbabwe.

₹ University of Johannesburg, South Africa.

(c) The Southern African Institute of Mining and Metallurgy, 2018. ISSN 2225-6253. Paper received Sept. 2016; revised paper received June 2017. 


\section{Effect of frother and depressant interaction on flotation of Great Dyke PGM ore}

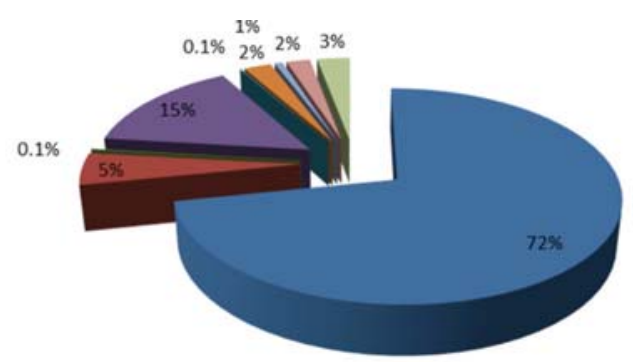

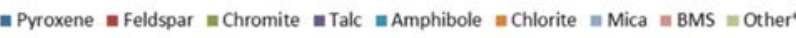

Figure 1-Bulk mineralogical composition (by mass) of the ore

\section{Materials and methods}

\section{Sample preparation}

Freshly ground underground ore was used for the experiments. A $4 \mathrm{~m}$ belt cut bulk sample was taken from the run-of-mine silo conveyor belt under normal plant operating conditions. The bulk sample weighed approximately $180 \mathrm{~kg}$. Rocks larger than $50 \mathrm{~mm}$ were crushed using a laboratory jaw crusher. The ore was further crushed using a Boyd crusher to a top size of $4 \mathrm{~mm}$ and the crushed ore was blended using a Y-blender. A ten-way rotating splitter was used to split the ore into $1.3 \mathrm{~kg}$ sub-samples, which were ground in a laboratory rod mill with a grind time of 12 minutes used in order to achieve a grind of $40 \%$ passing 75 $\mu \mathrm{m}$, which matches the product of the primary grinding circuit (primary rougher feed; MF1) at the operations. The rod mill discharge was wet-screened to produce a grind curve. The bulk mineralogical composition of the ore used is shown in Figure 1. It consisted mainly of pyroxene (72\%) and talc $(15 \%)$, which is a naturally floating gangue mineral.

Table I shows the base metal sulphide (BMS) distribution of the ore. Pyrrhotite, chalcopyrite, and pentlandite are generally associated with the economic PGMs (Lee, 1996). Of these three major sulphide minerals, chalcopyrite has been shown to be the most rapidly floating, followed by pentlandite, and the least floatable being pyrrhotite. Studies indicate that about $80 \%$ of the chalcopyrite can be recovered without any collector (Wiese and Harris, 2007).

\section{Flotation}

A Denver flotation cell was used at a rotor speed maintained at $1200 \mathrm{r} / \mathrm{min}$ for all batch flotation tests. The collector, sodium isobutyl xanthate (SIBX), was maintained at $300 \mathrm{~g} / \mathrm{t}$ for all batch tests while frother (SAS FROTH) and depressant (DLM), which is a mixture of natural and modified

\section{Table I}

\section{BMS distribution}

\begin{tabular}{|l|c|}
\hline Composition & $\%$ \\
\hline Pentlandite & 25.5 \\
Pyrrhotite & 39.1 \\
Pyrite & 7.1 \\
Chalcopyrite & 28.3 \\
Total & 100.0 \\
\hline
\end{tabular}

polysaccharides) dosages were varied. The froth was scraped from the cell every 15 seconds, using paddles which were custom-made to scrape just above the froth-pulp interface, for a total time of 25 minutes. The concentrates were collected and the solids and water masses recorded. Water was added to the cell after every scrape to maintain the pulp level in the cell. The initial and final spray water bottle masses were recorded and the difference calculated in order to obtain the amount of water added during scraping.

\section{Experimental full factorial design}

A full factorial experimental design approach was used to identify individual and interactive effects of frother and depressant. Full factorial experimental design is a useful tool for the study of the effect of the various process parameters. In the factorial design approach the interdependency of process variables can be studied with respect to targeted responses (Araujo and Brereton, 1996; Cochran and Co., 1999). The responses used were concentrate grade, $4 \mathrm{E}$ recovery, mass pull, and water recovery. The responses were tested for significance by the F-test. The confidence level was set at $95 \%$. The experiments were carried out using two factors at six levels as given in Table II. Samples were analysed using fire assay.

\section{Results and discussion}

\section{Effect of frother and depressant on mass pull}

Based on the established hypothesis, the frother and depressant have a significant effect on mass pull, as shown in Table III. These results are consistent with the main effects plots in Figure 2. The plots were observed to be steeper at low dosages; $20-60$ and 180-420 g/t for frother and depressant respectively (Figure 2). These results suggest that the effects of these reagents on mass pull are more pronounced at low dosage. An increase in frother dosage at low concentrations was observed to have a positive effect on mass pull. This is as expected since it has been generally accepted that increasing frother concentration stabilizes the froth, resulting in poor drainage of entrained gangue and recovery of both valuable and gangue minerals, hence the higher mass pull (Valenta and Harris, 1999). This also agrees with the work by Langevin (2000), which supports the contention that froth stability is increased with increasing frother concentration. On the other hand, increasing depressant dosage resulted in a decrease in mass pull due to destabilization of the froth and lowered entrainment (Wiese, Harris, and Bradshaw, 2009). It was also observed at high

Table II

Two-factorial by six-level experimental design for frother and depressant

\begin{tabular}{|l|l|l|l|l|l|l|}
\hline Factors & \multicolumn{6}{|c|}{ Varying dosages (levels) $\mathbf{g} / \mathbf{t}$} \\
\cline { 3 - 5 } & \multicolumn{7}{|c|}{} \\
\hline Frother & 20 & 40 & 60 & 80 & 100 & 120 \\
Depressant & 180 & 260 & 340 & 420 & 500 & 580 \\
Collector & 300 & 300 & 300 & 300 & 300 & 300 \\
& & & & & & \\
\hline
\end{tabular}




\section{Effect of frother and depressant interaction on flotation of Great Dyke PGM ore}

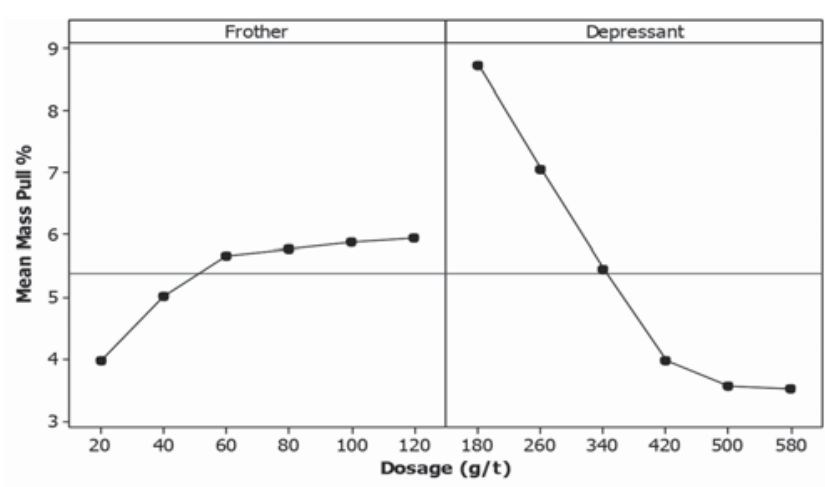

Figure 2-Main effect plots for mass pull

depressant concentration (420-580 g/t) that mass pull varied very little, suggesting that most material that is amenable to suppression has been suppressed.

The interaction of frother and depressant had a negative effect on mass pull. High dosages of both these reagents have an adverse effect on mass pull, hence dosage of these reagents should be monitored if the desired mass pull is to be maintained.

\section{Effect of frother and depressant on $4 E$ recovery}

From Figure 3 it can be observed that recovery increased with increasing frother concentration for low frother concentrations (20-60) g/t and thereafter almost levelled off. The initial increase in recovery with increase in frother quantity is expected as discussed earlier, due to entrainment. Changes in depressant concentration had no significant effect on recovery, which only fluctuated between $69 \%$ and $72 \%$. The insignificant effect of depressant on recovery could be due to a very low response of PGE-bearing minerals to an increase in depressant, e.g. chalcopyrite recovery is reported not to be affected by depressants while pentlandite is affected only at high dosages (Wiese and Harris, 2007). According to Corin and Reddy (2011), who used nickel and copper as indicators of the response of PGE-bearing minerals, only a

\section{Table III}

Summary of major effects of variables and interactions on responses at $95 \%$ confidence level

\begin{tabular}{|c|c|c|c|}
\hline Response & Term & $P$ value & $\begin{array}{l}\text { Effect on } \\
\text { response }\end{array}$ \\
\hline Mass pull & $\begin{array}{c}\text { Frother dosage } \\
\text { Depressant dosage } \\
\text { Frother*depressant }\end{array}$ & $\begin{array}{l}0.000 \\
0.000 \\
0.000\end{array}$ & $\begin{array}{l}\text { Significant }(+) \\
\text { Significant }(-) \\
\text { Significant }(-)\end{array}$ \\
\hline 4E PGE recovery & $\begin{array}{c}\text { Frother dosage } \\
\text { Depressant dosage } \\
\text { Frother*depressant }\end{array}$ & $\begin{array}{l}0.000 \\
0.552 \\
0.030\end{array}$ & $\begin{array}{l}\text { Significant }(+) \\
\text { Insignificant } \\
\text { Significant }(-)\end{array}$ \\
\hline $\begin{array}{l}\text { 4E concentrate } \\
\text { grade }\end{array}$ & $\begin{array}{c}\text { Frother dosage } \\
\text { Depressant dosage } \\
\text { Frother*depressant }\end{array}$ & $\begin{array}{l}0.264 \\
0.000 \\
0.240\end{array}$ & $\begin{array}{l}\text { Insignificant } \\
\text { Significant (+) } \\
\text { Insignificant }\end{array}$ \\
\hline Water recovery & $\begin{array}{c}\text { Frother dosage } \\
\text { Depressant dosage } \\
\text { Frother*depressant }\end{array}$ & $\begin{array}{l}0.000 \\
0.000 \\
0.000\end{array}$ & $\begin{array}{ll}\text { Significant } & (+) \\
\text { Significant } & (-) \\
\text { Significant } & (-)\end{array}$ \\
\hline
\end{tabular}

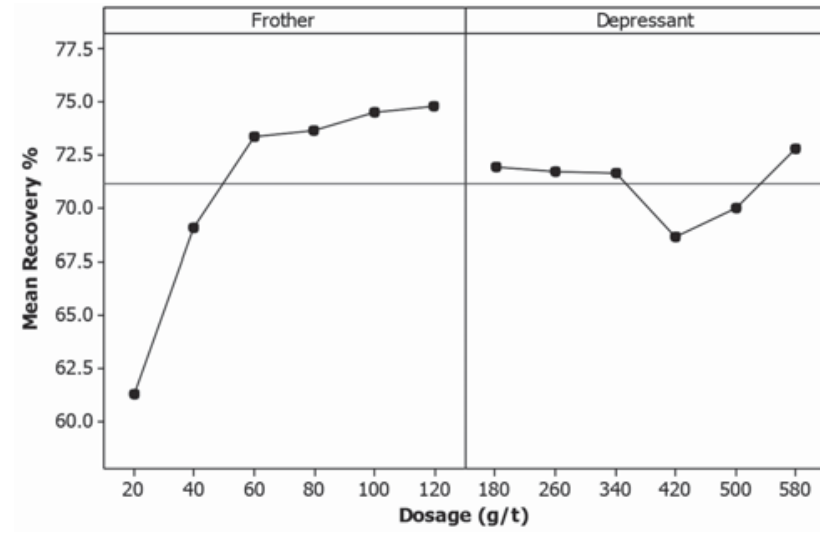

Figure 3- Recovery main effect plots

high depressant dosage of $500 \mathrm{~g} / \mathrm{t}$ had an influence on maximum recovery. However, in this work depressant concentration had no effect on recovery, suggesting that the depressant at the investigated dosages (up to $580 \mathrm{~g} / \mathrm{t}$ ) did not suppress PGMs significantly and that the gangue material was mainly suppressed (McFadzean and Pani, 2015). This results in a continual increase in grade at the expense of the gangue material, as depicted in Figure 4.

The probability $(\mathrm{P})$ values in Table III indicate that depressant-frother interactions had a significant negative effect on the recovery of valuable minerals, similarly to mass pull.

\section{Effect of frother and depressant on concentrate grade}

Figure 4 indicates the effect of increasing both frother and depressant on the concentrate grade. The concentrate grade increased with an increase in depressant dosage while the frother was observed to have insignificant effect on the grade. These results support the earlier assumption that depressant significantly suppressed only gangue minerals, and hence decreased the mass pull and increased the concentrate grade but had no effect on recovery. A slight drop in grade from 41 to $35 \mathrm{~g} / \mathrm{t}$ was observed with increasing frother concentration (Table III), possibly as a result of the increase in mass pull due to entrainment, shown in Figure 2. These results suggest that the minimum amount of frother should be added that produces a sufficiently stable froth and

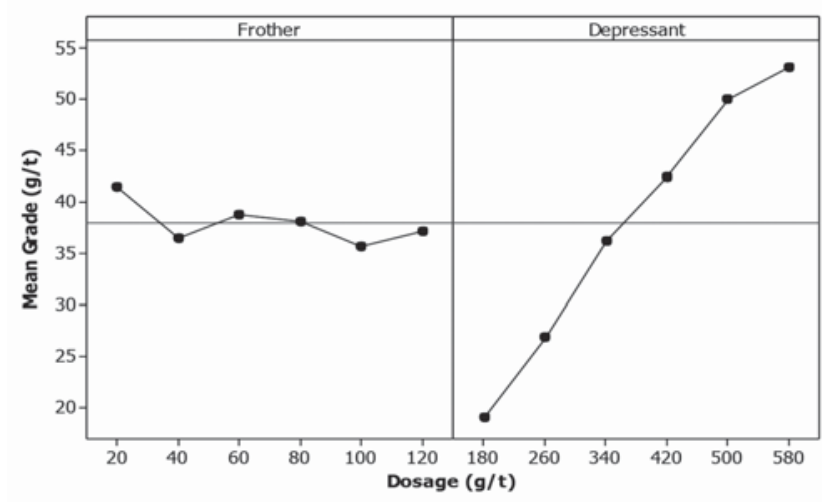

Figure 4 - Concentrate grade versus frother and depressant dosage 


\section{Effect of frother and depressant interaction on flotation of Great Dyke PGM ore}

an acceptable mass pull. It was also observed that frotherdepressant interactions were insignificant. The absence of interactions means that concentrate grade can be optimized by fixing one variable and varying another.

\section{Effect of frother and depressant on water recovery}

As shown in Figure 5, water recovery increased with increasing frother quantity between 20 and $60 \mathrm{~g} / \mathrm{t}$. This is a similar trend to that observed for mass pull and recovery, suggesting the increase in mass pull and recovery is due to entrainment (Wiese and Harris, 2007). Increasing frother dosages increase solid recovery due to the stable froth which reduces selectivity and leads to non-selective entrainment (Yoon and Luterell, 1989). Water recovery was also observed to decline with increasing depressant quantities above 340 $\mathrm{g} / \mathrm{t}$. This suggests that froth stability is affected by depressant and frother-depressant interactions at high depressant concentrations (above $340 \mathrm{~g} / \mathrm{t}$ ), hence a decrease in water recovery. These results are consistent with observations that bubble formation was poor at depressant concentrations from 420-580 g/t. Similar findings were obtained by Ekmeckci and Bradshaw (2003) at high depressant dosages. Wiese (2011) stated that depressants have a significant effect on water recovery

From Table III it can be seen that frother had a positive effect on water recovery, while depressant had negative effect, in agreement with Figure 5. However, a closer look at Figure 5 shows that the negative effect of depressant was more pronounced at high dosages $(420-580 \mathrm{~g} / \mathrm{t})$.

\section{Optimization}

The main effects graphs do not enable process optimization but enable the effect of various process parameters to be investigated. For the purposes of optimization, only results based on low depressant dosages (180-340 g/t ) were analysed. High dosage were not considered because of the poor froth stability observed, as discussed earlier, hence they will be of no practical use at a plant scale. Figure 6 was produced by assuming equal importance for both recovery and grade (Venkatesan and Harris, 2014). From Figure 6 it can be seen that the areas that give best values for the normalized product are towards high depressant and low frother concentration. Taking the first region or contour with a depression dosage range of 280-340 g/t and frother dosage range of $20-80 \mathrm{~g} / \mathrm{t}$ as the optimum region, regardless of other values not included in test work $(280,300,320 \mathrm{~g} / \mathrm{t})$, the

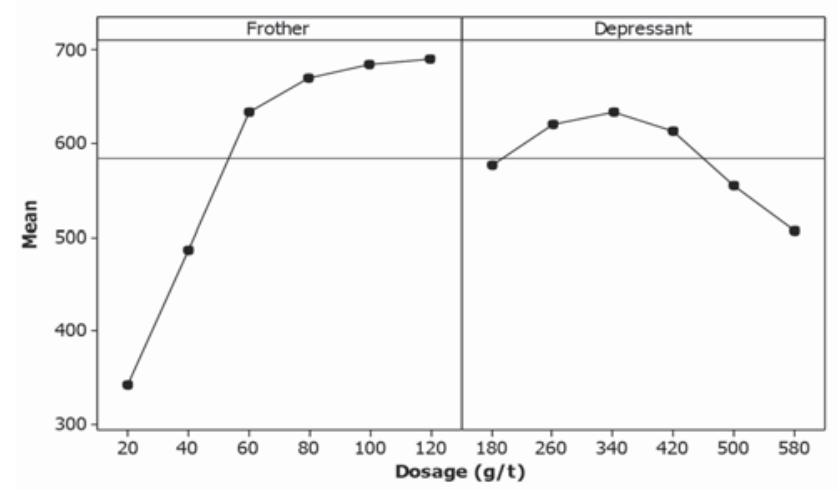

Figure 5 - Water recovery main effect plot

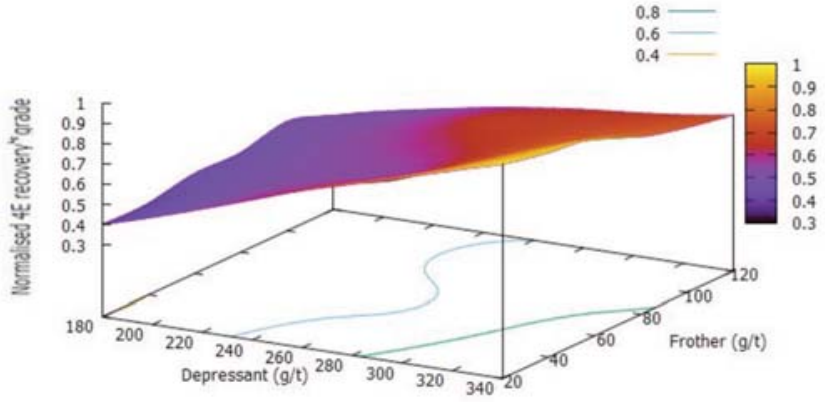

Figure 6-Surface plot for normalized 4E recoverygrade

range of recovery and grade in this region is $61-74 \% 4 \mathrm{E}$ recovery and 31-44 g/t concentrate grade. Further investigations of reagent combinations in this region are recommended to verify the suggested values.

When grade is considered more important than recovery, the index of recovery* grade 2 is used. From Figure 7, it can be seen that the number of regions marked by contours increased from the previous three to five. This results in small regions, meaning that if the importance of grade is doubled there is a need for stricter reagent control and optimization. Figure 7 agrees with earlier findings that frother had minimal effect on grade compared to depressant. The contour line shifts from $280 \mathrm{~g} / \mathrm{t}$ to approximately $330 \mathrm{~g} / \mathrm{t}$ depressant if the importance of grade is doubled compared to the frother, which only declined to approximately $70 \mathrm{~g} / \mathrm{t}$ from $80 \mathrm{~g} / \mathrm{t}$ (Figure 6).

\section{Analysis of interdependence of responses}

Figure 8 shows $4 \mathrm{E}$ recovery and mass pull as a function of water recovery. There is a reasonable good linear relationship for both $4 \mathrm{E}$ recovery and mass pull versus water recovery for varying frother dosage. A good correlation with water recovery suggests that the variables mass pull and recovery are dependent solely on entrainment (Valenta and Harris, 1999).

When the depressant concentration was varied no correlation was observed between water recovery, mass pull, and $4 \mathrm{E}$ recovery. This suggests the depressant is selective, as opposed to the frother, which increases entrainment with increased dosage.

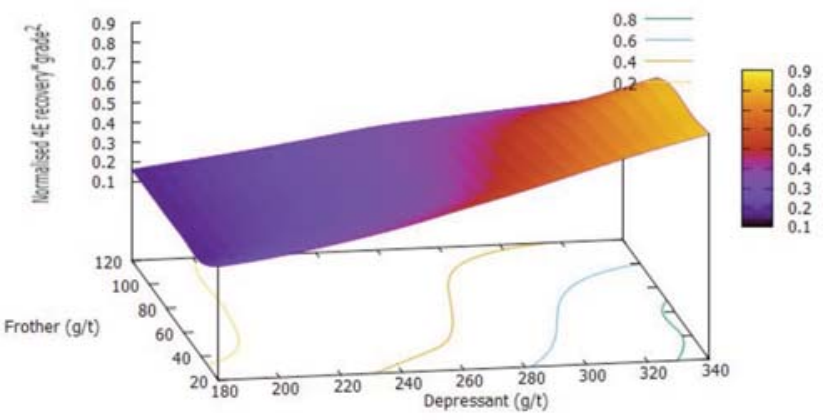

Figure 7-Surface plot for normalized 4E recovery ${ }^{\star}$ grade $^{2}$ 


\section{Effect of frother and depressant interaction on flotation of Great Dyke PGM ore}

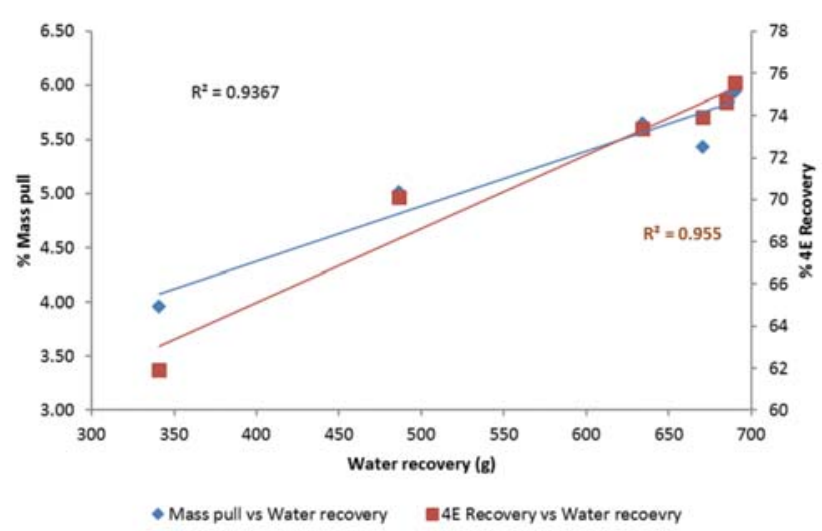

Figure 8-Water recovery versus recovery and mass pull

\begin{tabular}{|c|c|c|c|c|}
\hline \multicolumn{5}{|c|}{$\begin{array}{l}\text { Table IV } \\
\text { Summary of results }\end{array}$} \\
\hline \multirow[t]{2}{*}{ Reagent } & \multicolumn{4}{|c|}{ Effect on } \\
\hline & Grade & Recovery & Mass pull & Water recovery \\
\hline Frother & No & Yes & Yes & Yes \\
\hline Depressant & Yes & No & Yes & Yes \\
\hline Frother*Depressant & No & Yes & Yes & Yes \\
\hline
\end{tabular}

\section{Conclusion}

Based on the F-test at 95\% confidence level, the results can be summarized as in Table IV.

Increase in frother dosage resulted in an increase in recovery and mass pull due to entrainment, as corroborated by an increase in water recovery. A slight drop in grade was observed, hence frother dosage can be manipulated to achieve a desired PGE recovery without significantly affecting grade.

An increase in depressant resulted in an increase in grade and a decrease in mass pull. Depressant had an insignificant effect on recovery, suggesting that there was selective suppression of gangue minerals in the range investigated. Frother-depressant interactions had a negative effect on mass pull, $4 \mathrm{E}$ recovery, and water recovery, but an insignificant effect on concentrate grade. Assuming equal importance of $4 \mathrm{E}$ recovery and concentrate grade, the optimum reagent dosage range was 280-340 g/t depressant and 20-80 g/t frother.

\section{Recommendations}

As stated above, assuming equal importance of 4E recovery and concentrate grade the optimum reagent dosage range is 280-340 g/t depressant and 20-80 g/t frother. Further test work is therefore recommended to narrow this range. Furthermore, this range may be investigated using threefactorial experimental design to incorporate the effect of collector. The reagents used and the ranges should be representative of the plant-scale flotation circuit.

\section{References}

Araujo, P.W. and Brereton, R.G. 1996. Experimental design II. Optimisation. TaAC Trends in Analytical Chemistry, vol. 15, no. 2. pp. 63-70.

Cochran, W.G. and Cox, G.M. 1990. Disefios Experimentales, 2nd edn. Trillas, Mexico.

CoRIN, K., and REDDY, A.M.L. 2011. The effect of ionic strength of plant water on valuable mineral and gangue recovery in a platinum bearing ore from the Merensky reef. Minerals Engineering, vol. 24, no. 2. pp. 131-137.

Екмесксі, Z. and BRADSHAw, D.A. 2003. Effects of frother type and froth height on the flotation behaviour of chromite in UG2 ore. Minerals Engineering, vol. 16, no. 10. pp. 941-949.

LANGEVIN, D. 2000. Influence of interfacial rheology on foam and emulsion properties. Advances in Colloid and Interface Science, vol. 88, no. 1-2. pp. 209-222.

LEE, C. 1996. A review of mineralisation in the Bushveld Complex and some other layered intrusions. Developments in Petrology, vol. 15. pp.103-145.

McFadzeAn, B. and Pani, S.W. 2015. The interactive effects of chemical and process parameters on the flotation performance of a UG2 ore. Minerals Engineering, vol. 70. pp. 92-98.

NASHwA, V.M. 2008. The flotation of high talc containing ore from the Great Dyke. MSc thesis, University of Pretoria.

Oberthur, T., Muller, P., and LodZIAK, J. 1999. Mobility of PGE and PGM in the supergene environment at the Hartley Mine, Great Dyke. A case study. Mineral Deposits - Processes to Processing. Proceedings of the Fifth Biennial SGA Meeting and the Tenth Quadrennial IAGOD Symposium, London, UK, 22-25 August. Balkema. pp. 763-766.

Prendergast, M. 1988. The geology and economic potential of the PGE-rich Main Sulphide Zone of the Great Dyke, Zimbabwe. Proceedings of Geoplatinum 87, Open University, UK. Prendergast, M. (ed.). Springer, Dordrecht. pp. 281-302.

Prendergast, M. 1990 Platinum-group minerals and hydrosilicate 'alteration' in Wedza-Mimosa platinum deposit, Great-Dyke, Zimbabwe, Genetic and metallurgical implication. Transactions of the Institution of Mining and Metallurgy Section B: Applied Earth Science, vol. 99. pp. B91-B105.

VALENTA, M. and HARRIS, P.J. 1999. The contribution of entrainment to the UG2 ore. Proceedings of the Mineral Processing Conference, Cape Town.

Venkatesan, L. and Harris A.G.M. 2014. Optimisation of air rate and froth depth in flotation using a CCRD factorial design - PGM case study. Minerals Engineering, vol. 60-68. pp. 221-229.

Wiese, J., HARRRIS, P.J., and Bradshaw, D. 2009. The effect of increased frother dosage on froth stability at high depressant dosages. Flotation 09. Proceedings of: 4th International Flotation Conference, Cape Town, 9-12 November 2009. Bradshaw, J., Franzidis, J.-P., and Wills, B.A. (eds). pp. 1010-1017. doi:10.1016/j.mineng.2010.04.011

WIESE, J. and HARRIS, P.B. 2007. The response of sulphide and gangue minerals in selected Merensky ores to increased depressant dosages. Minerals Engineering, vol. 20, no. 10. pp. 986-995.

WIESE, J. (2011). The effect of the reagent suite on froth stability in laboratory scale batch flotation tests. Minerals Engineering, vol. 24. pp. 995-1003.

Yoon, R.H. and LutTReLL, G.H. 1989. The effect of bubble size on fine particle flotation, Mineral Processing and Extractive Metallurgy Review, vol. 5, no. 1-4. pp. 101-122. 